\title{
Marine Bacteria, A Source for Alginolytic Enzyme to Disrupt Pseudomonas aeruginosa Biofilms
}

\author{
Said M. Daboor ${ }^{1,3, *}$, Renee Raudonis ${ }^{1}$, Alejandro Cohen ${ }^{2}$, John R. Rohde ${ }^{1}$ \\ and Zhenyu Cheng ${ }^{1, * \mathbb{D}}$ \\ 1 Department of Microbiology and Immunology, Dalhousie University, Halifax, \\ Nova Scotia, NS B3H 4R2, Canada; r.raudonis@dal.ca (R.R.); john.rohde@dal.ca (J.R.R.) \\ 2 Department of Biochemistry and Molecular Biology, Dalhousie University, Halifax, \\ Nova Scotia, NS B3H 4R2, Canada; alejandro.cohen@dal.ca \\ 3 National Institute of Oceanography and Fisheries, Cairo 11516, Egypt \\ * Correspondence: said.daboor@dal.ca (S.M.D.); zhenyu.cheng@dal.ca (Z.C.); Tel.: +1-902-494-7829
}

Received: 3 May 2019; Accepted: 22 May 2019; Published: 24 May 2019

\begin{abstract}
Pseudomonas aeruginosa biofilms are typically associated with the chronic lung infection of cystic fibrosis (CF) patients and represent a major challenge for treatment. This opportunistic bacterial pathogen secretes alginate, a polysaccharide that is one of the main components of its biofilm. Targeting this major biofilm component has emerged as a tempting therapeutic strategy for tackling biofilm-associated bacterial infections. The enormous potential in genetic diversity of the marine microbial community make it a valuable resource for mining activities responsible for a broad range of metabolic processes, including the alginolytic activity responsible for degrading alginate. A collection of 36 bacterial isolates were purified from marine water based on their alginolytic activity. These isolates were identified based on their $16 \mathrm{~S}$ rRNA gene sequences. Pseudoalteromonas sp. 1400 showed the highest alginolytic activity and was further confirmed to produce the enzyme alginate lyase. The purified alginate lyase (AlyP1400) produced by Pseudoalteromonas sp. 1400 showed a band of $23 \mathrm{KDa}$ on a protein electrophoresis gel and exhibited a bifunctional lyase activity for both poly-mannuronic acid and poly-glucuronic acid degradation. A tryptic digestion of this gel band analyzed by liquid chromatography-tandem mass spectrometry confirmed high similarity to the alginate lyases in polysaccharide lyase family 18 . The purified alginate lyase showed a maximum relative activity at $30{ }^{\circ} \mathrm{C}$ at a slightly acidic condition. It decreased the sodium alginate viscosity by over $90 \%$ and reduced the P. aeruginosa (strain PA14) biofilms by $69 \%$ after $24 \mathrm{~h}$ of incubation. The combined activity of AlyP1400 with carbenicillin or ciprofloxacin reduced the P. aeruginosa biofilm thickness, biovolume and surface area in a flow cell system. The present data revealed that AlyP1400 combined with conventional antibiotics helped to disrupt the biofilms produced by P. aeruginosa and can be used as a promising combinational therapeutic strategy.
\end{abstract}

Keywords: marine bacteria; Pseudomonas aeruginosa; biofilm; alginate lyase

\section{Introduction}

Bacterial biofilms represent the dominant bacterial growth lifestyle in different habitats, including natural and clinical environments [1-5]. Bacterial cells switch between the free-living planktonic mode and biofilm growth mode through multiple stages that include adhesion to a substratum, increasing their aggregation into micro-colonies and maturation of biofilms via matrix formation through secretion of extracellular polymeric substances [6-8]. It is estimated that $65 \%-80 \%$ of human infections involve biofilms, causing a huge burden on healthcare systems globally $[5,9,10]$. 
Pseudomonas aeruginosa is an opportunistic pathogen with the ability to colonize a wide range of hosts and/or substrates and produce biofilms. Pseudomonas aeruginosa biofilms are commonly found in patients with cystic fibrosis $(\mathrm{CF})$ and chronic obstructive pulmonary disease with persistent infections. This bacterium also forms biofilms on medical devices, such as central venous and urinary catheters, stents, orthopedic prosthesis, and mechanical heart valves, causing infections that are extremely difficult to treat, and thus have a massive impact on healthcare funding [11-14].

Pseudomonas aeruginosa cells within biofilms demonstrate a slow growth rate that endures many therapeutic antimicrobial agents due to substantially diminished antibiotic diffusions $[15,16]$, and causes weakened cell-mediated host defenses [17-19]. As a result, the clinical management of those biofilm-ensconced bacteria has become intractable [11,20]. The failure to eradicate the pathogen from the lung often leads to increased possibility of chronic infections that are connected by acute exacerbations of disease and inflammation, resulting in lung failure and high morbidity among patients [21-26]. However, P. aeruginosa biofilm infections go beyond CF diseases, especially with diabetic patients. These patients are prone to developing chronic wounds that lack sufficient healing capabilities, thus resulting in biofilm-associated, long-term infections, which cause financial burdens for the patients $[9,27,28]$.

The treatment of $P$. aeruginosa established biofilms with enzymes that degrade the biofilm matrix have been widely used as an alternative treatment approach for bacterial infection. The levanase SacC [29], DNase (NucB) that hydrolyzes the eDNA within the extracellular matrix [30], and glycoside hydrolase that hydrolyzes the biofilm exopolysaccharide [31] have all been shown to act against $P$. aeruginosa biofilm. The overproduction of the polysaccharide alginate is the major cause for the mucoid phenotype of $P$. aeruginosa that is associated with a decline in lung function. Cultures of CF patients' sputum showed high amounts of alginate and a massive production of antibodies against alginates including IgG and IgA classes [4,11]. Moreover, alginate is a major component of P. aeruginosa biofilms, making it an attractive target to limit biofilm-associated infections of this extremely important bacterial pathogen. Disrupting alginate structure will potentially promote the killing rate of bacterial pathogens by human immune cells and improve antipseudomonal antibiotic efficacy. The use of alginate lyase was considered as an approach to improve treatment for bacterial infections within biofilm by breaking down the main part of biofilm matrix [32]. Marine bacteria are known to be a potential source for alginate lyase, due to the high possibility of encountering alginate that is rich in their environment, as it is a cell wall component of brown algae [33]. Pseudoalteromonas, a marine bacterium that produces exoproducts including alginate lyase, demonstrated antibacterial activity against many pathogenic bacteria, such as Salmonella enterica, Staphylococcus aureus, P. aeruginosa, Escherichia coli and Enterococcus faecalis [34] and antibiofilm activity against S. enterica, P. aeruginosa and E. coli [35]. In this work, we purified alginate lyase from a Pseudoalteromonas isolate. Importantly, we showed that the purified alginate lyase was able to disrupt the established biofilm of P. aeruginosa. This study will facilitate the development of a combinational therapeutic strategy, by using alginate lyase and antibiotics, to tackle the problem of P. aeruginosa biofilm-associated infections.

\section{Results}

\subsection{Isolation of Bacterial Strains with Alginolytic Activity}

A total of 36 bacterial strains with alginate lyase activity were isolated after enrichment on bacterial agar plates containing sodium alginate and selected for 16S rRNA sequencing (GenBank accession numbers MK377259 through MK377294). The 16S rRNA sequence analysis revealed that most obtained strains belong to five genera, Celeribacter, Cellulophaga, Pseudoalteromonas, Shewanella, and Vibro. As shown in Table 1, Pseudoalteromonas spp. represented 52\% of the identified isolates (19 out of 36 isolates). Alginate lyase activity was determined based on the hydrolytic clearance zone diameter produced after adding the Lugol's solution to alginate plates. Seven bacterial isolates (No. 1400, 1403, 1413, 1416, 1421, 1422 and 1423) that produced the highest alginate lyase activity by 
exhibiting the largest clear zones are highlighted in bold in Table 1. Isolate 1400 produced the largest clearing hydrolytic zone with a diameter of $30.0 \pm 1.4 \mathrm{~mm}$. The $16 \mathrm{~S}$ rRNA gene sequence of the isolate 1400 showed highest identity (99\%) to a Pseudoalteromonas tetraodonis strain GFC. Based on these results, isolate 1400 was designated as Pseudoalteromonas sp. 1400. The cell-free supernatant of medium that had been used to culture this strain contained a total alginolytic activity of $70.09 \pm 1.72 \mathrm{U} / \mathrm{mL}$ (Figure 1a) and significantly $(P<0.0001)$ reduced sodium alginate solution viscosity to $2.23 \pm 0.25$ centipoise with $90.81 \%$ liquefaction after $24 \mathrm{~h}$ incubation (Figure 1a), while sodium alginate solution (the blank) viscosity was $24.28 \pm 1.12$ centipoise (Figure $1 \mathrm{~b}$ ). The plate assay technique was used to detect the enzyme substrate specificity. After covering the alginate agar plate with $1 \mathrm{M} \mathrm{CaCl}_{2}$ solution, enzymes acting on poly-mannuronate (poly-M) will show a white halo due to gelation of the degradation products caused by the reaction of lyase with poly-M. Meanwhile, poly-guluronate (poly-G) substrate will show a white ring, due to the depolymerization of alginate to uronic acid. Appearance of both phenomena, as clearly observed by Pseudoalteromonas sp. 1400 supernatant indicated that its alginolytic enzyme possessed substrate specificity for both poly-G and poly-M (Figure 2).

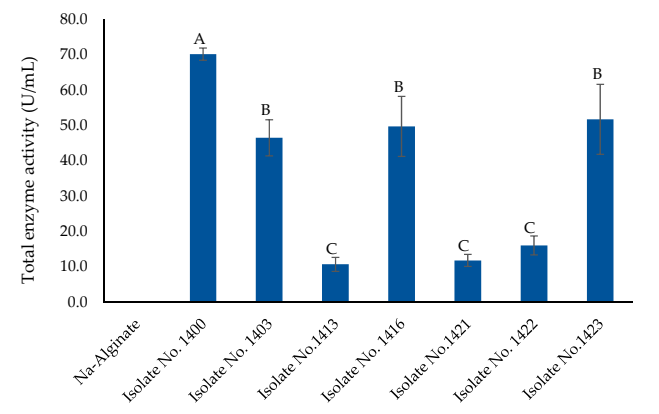

(a)

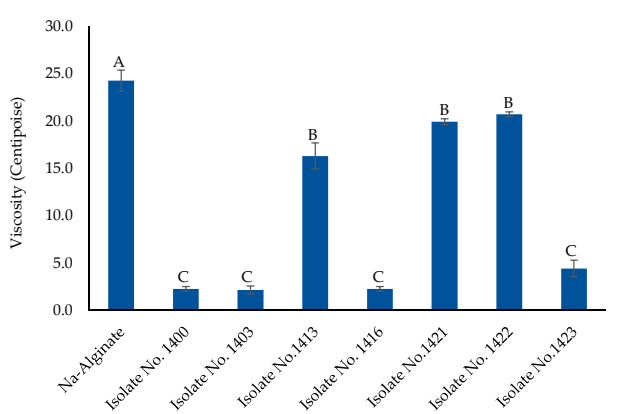

(b)

Figure 1. Alginate lyase activity produced by different bacterial strains. (a) Total enzyme activity represented as unit per $\mathrm{mL}$, where each one-unit enzyme is defined as the amount of enzyme required to increase the absorbance at $235 \mathrm{~nm}$ by 0.01 per minute. (b) Viscosity reduction of selection medium with $1.8 \%$ sodium alginate after $24 \mathrm{~h}$ incubation measured in centipoise, a unit of absolute viscosity. Error bars represent standard deviation of three independent experiments. The blank is designated as Na-alginate (sodium alginate). Different letters indicate a statistically significant difference between groups $(p<0.05)$.

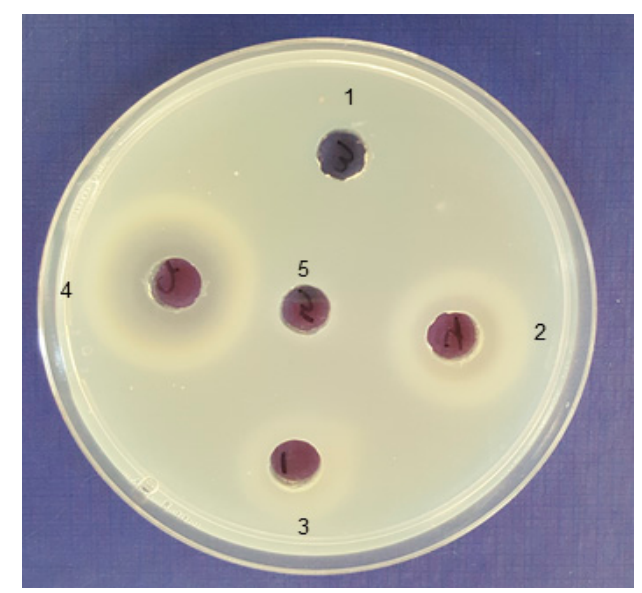

Figure 2. Bifunctional activity of alginate lyase produced by isolated marine bacteria. Enzymes acting against poly-mannuronate (poly-M) show a white halo due to gelation of the degradation products caused by the reaction of lyase with poly-M and enzymes acting against poly-guluronate (poly-G) show a white ring. The lyase activity of the following isolates' supernatants are shown: 1, Cellulophaga sp. 1423; 2, Pseudoalteromonas sp. 1422; 3, Pseudoalteromonas sp. 1416; 4, Pseudoalteromonas sp. 1400; and 5, well is filled with $1.8 \%$ alginate solution in $20 \mathrm{mM}$ Tris- $\mathrm{HCl}$ buffer as a blank. 
Table 1. Identities and alginate lyase activity of isolated bacterial strains.

\begin{tabular}{|c|c|c|}
\hline No. & The Most Closely Related Bacterial Species Name and Sequence ID from GenBank & $\begin{array}{l}\text { Alginate Lyase Activity } \\
\text { (Clearing Zone, mm) * }\end{array}$ \\
\hline 101 & Pseudoalteromonas carrageenovora IAM 12662 strain ATCC43555T, LT965929.1 & $12.0 \pm 1.4$ \\
\hline 1002 & Celeribacter halophilus strain Xmb039, KT986167.1 & $10.5 \pm 2.1$ \\
\hline 2001 & Shewanella algae strain SFH3, MG738264.1 & $9.5 \pm 0.7$ \\
\hline 2005 & Vibrio parahaemolyticus strain HH101313, MG386398.1 & $14.5 \pm 0.7$ \\
\hline 2006 & Shewanella algae strain KC-Na-R1, CP033575.1 & $6.5 \pm 0.7$ \\
\hline 4001 & Vibrio natriegens strain AUCASVE5, JQ277719.1 & $7.0 \pm 1.4$ \\
\hline 4002 & Vibrio alginolyticus strain QY170324, MF101235.1 & $6.0 \pm 1.4$ \\
\hline 4003 & Vibrio alginolyticus strain QY170324, MF101235.1 & $8.0 \pm 1.4$ \\
\hline 4005 & Vibrio parahaemolyticus strain SC2, MK308579.1 & $10.0 \pm 1.4$ \\
\hline 6002 & Vibrio azureus strain Xmb005, KT986135.1 & $10.5 \pm 2.1$ \\
\hline 6006 & Vibrio alginolyticus strain FDAARGOS_114, СP014045.1 & $3.0 \pm 1.4$ \\
\hline 8009 & Vibrio alginolyticus strain QY170324, MF101235.1 & $11.0 \pm 1.4$ \\
\hline 9001 & Vibrio parahaemolyticus strain CHB-33, KR347290.1 & $5.5 \pm 2.1$ \\
\hline 9002 & Vibrio alginolyticus strain CX-72, MH368392.1 & $4.5 \pm 0.7$ \\
\hline 9003 & Vibrio alginolyticus strain Val-3, MH879822.1 & $6.5 \pm 2.1$ \\
\hline 9004 & Vibrio diabolicus strain FDAARGOS_96, CP014094.1 & $7.5 \pm 0.7$ \\
\hline 1400 & Pseudoalteromonas tetraodonis strain GFC, СР011041.1 & $30.0 \pm 1.4$ \\
\hline 1401 & Pseudoalteromonas carrageenovora IAM 12662 strain ATCC43555T, LT965929.1 & $2.5 \pm 0.7$ \\
\hline 1403 & Pseudoalteromonas agarivorans strain SDRB-Py1, MG456901.1 & $27.5 \pm 0.7$ \\
\hline 1404 & Pseudoalteromonas distincta strain 20KNS10Z3, MH478310.1 & $4.0 \pm 1.4$ \\
\hline 1405 & Pseudoalteromonas carrageenovora IAM 12662 strain ATCC43555T, LT965929.1 & $11.0 \pm 1.4$ \\
\hline 1406 & Pseudoalteromonas agarivorans strain DSM 14585, NR_025509.1 & $6.5 \pm 0.7$ \\
\hline 1407 & Pseudoalteromonas tetraodonis strain GFC, CP011041.1 & $2.5 \pm 0.7$ \\
\hline 1408 & Pseudoalteromonas tetraodonis strain GFC, СР011041.1 & $11.0 \pm 1.4$ \\
\hline 1410 & Pseudoalteromonas tetraodonis strain GFC, СP011041.1 & $12.0 \pm 1.4$ \\
\hline 1412 & Pseudoalteromonas atlantica strain ECSMB14104, CP023464.1 & $5.0 \pm 0.0$ \\
\hline 1413 & Cellulophaga fucicola strain NN015860, NR_025287.1 & $17.5 \pm 1.4$ \\
\hline 1414 & Pseudoalteromonas carrageenovora IAM 12662 strain ATCC43555T, LT965929.1 & $14.5 \pm 0.7$ \\
\hline 1416 & Pseudoalteromonas carrageenovora IAM 12662 strain ATCC43555T, LT965929.1 & $20.5 \pm 0.7$ \\
\hline 1417 & Pseudoalteromonas carrageenovora IAM 12662 strain ATCC43555T, LT965929.1 & $9.5 \pm 0.7$ \\
\hline 1418 & Alteromonas stellipolaris strain PQQ-44, CP015346.1 & $10.0 \pm 1.4$ \\
\hline 1419 & Pseudoalteromonas tetraodonis strain GFC, СР011041.1 & $13.5 \pm 2.1$ \\
\hline 1421 & Pseudoalteromonas carrageenovora IAM 12662 strain ATCC43555T, LT965929.1 & $24.0 \pm 1.4$ \\
\hline 1422 & Pseudoalteromonas carrageenovora IAM 12662 strain ATCC43555T, LT965929.1 & $24.0 \pm 1.4$ \\
\hline 1423 & Cellulophaga fucicola strain NN015860, NR_025287.1 & $21.5 \pm 2.1$ \\
\hline 1427 & Pseudoalteromonas espejiana strain ATCC 29659, СР011028.1 & $7.5 \pm 0.7$ \\
\hline
\end{tabular}

Notes: The bacterial strains with the largest clearing zones that were further used in this study are shown in bold font. * The mean values of three independent experiments are presented as means \pm standard deviation, $\operatorname{SD}(n=3)$.

\subsection{Antibiofilm Activity of Cell-Free Supernatants of Seven Isolates}

The cell-free supernatants of seven bacterial strains (listed in bold in Table 1 above) were screened for antibiofilm activity against $P$. aeruginosa strain PA14. Pre-formed biofilms (48 h) in a 96-well microplate were treated with the cell-free supernatant of each bacterial strain or medium control. The remaining biofilm was stained using crystal violet and the relative biomass was measured using absorbance at $570 \mathrm{~nm}$. Our data revealed that the supernatants from all isolates disrupted the established PA14 biofilm (Figure 3). Pseudoalteromonas sp. 1400 supernatant treatment led to a 69\% reduction in PA14 biofilm biomass. There were no significant changes $(P \geq 0.05)$ for the majority of the tested supernatants in biofilm disruption efficiencies between the $24 \mathrm{~h}$ and $48 \mathrm{~h}$ (Figure S1) treatment period. 


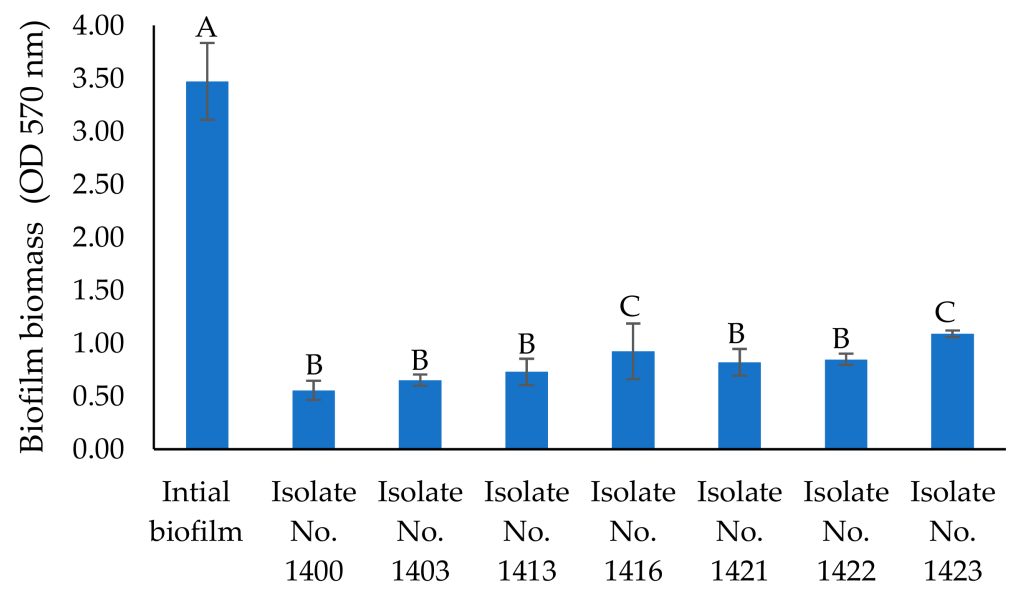

Figure 3. Biofilm biomass formed after $48 \mathrm{~h}$ in 96-well microplates, treated with different cell-free supernatants for $24 \mathrm{~h}$ at $37^{\circ} \mathrm{C}$ under static conditions. Error bars represent standard deviation (SD) of three independent experiments. Different letters indicate statistically significant differences between groups $(p<0.05)$.

\subsection{Alginate Lyase Production and Purification}

Isolate 1400 was selected for subsequent enzyme purification and characterization because it demonstrated the best and highest alginate lyase activity as shown by having the largest clearance zone (Table 1) and enzyme production measured in $\mathrm{U} / \mathrm{mL}$ (Figure 1a). First, we set to optimize the growth conditions (including temperature and medium $\mathrm{pH}$ ), under which Pseudoalteromonas sp. 1400 produced the highest alginate lyase activity in the supernatant. We recorded a specific enzyme activity of $34.4 \mathrm{U} / \mathrm{mg}$ protein with $47.17 \pm 4.45 \mathrm{U} / \mathrm{mL}$ total activity when incubated at $25^{\circ} \mathrm{C}$. This activity was significantly reduced $(P<0.001)$ when incubated at lower temperature, i.e., $10^{\circ} \mathrm{C}$. At $35^{\circ} \mathrm{C}$ and $40{ }^{\circ} \mathrm{C}$, only $8.7 \mathrm{U} / \mathrm{mg}$ protein was released. Meanwhile, no alginate lyase activity was detected with growth performed at $45^{\circ} \mathrm{C}$ (Figure 4a). On the other hand, Pseudoalteromonas sp. 1400 grown at $\mathrm{pH} 8.0$ released the highest amount of alginate lyase with specific activity of $32.85 \mathrm{U} / \mathrm{mg}$ protein and $56.5 \pm 0.71 \mathrm{U} / \mathrm{mL}$ total activity, whereas we noticed that the lowest specific enzyme activity (5.92 $\mathrm{U} / \mathrm{mg}$ protein) was recorded at pH 5.0 and $\mathrm{pH}$ 6.0. As shown in Figure 4b, there was no lyase activity detectable at pH 4.0.

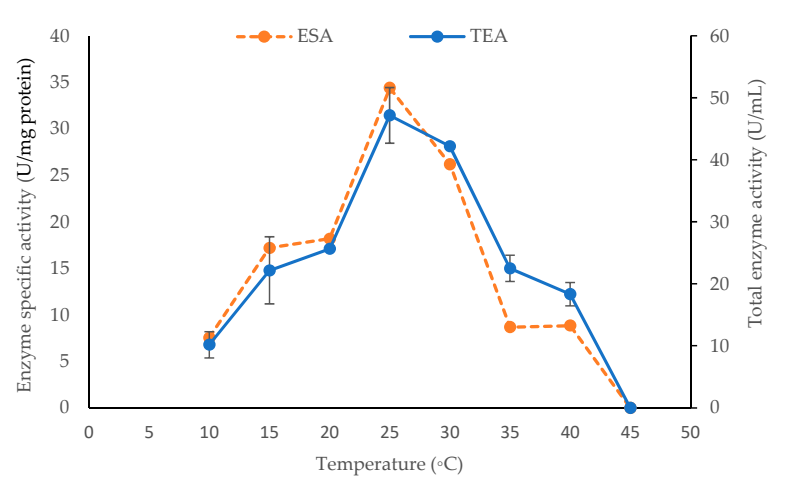

(a)

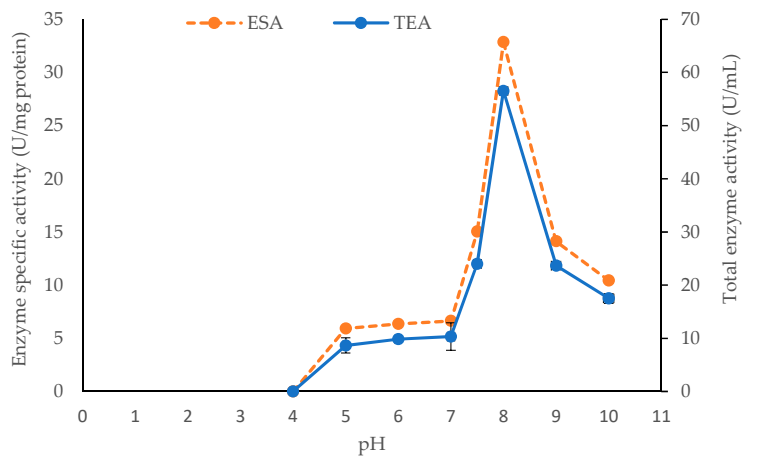

(b)

Figure 4. The alginate lyase enzyme specific activity (ESA) and total enzyme activity (TEA) produced by Pseudoalteromonas sp. 1400 after $24 \mathrm{~h}$ incubation at $150 \mathrm{rpm}$ with (a) different temperatures and (b) different $\mathrm{pH}$ values. One-unit enzyme is defined as the amount of enzyme required to increase the absorbance at $235 \mathrm{~nm}$ by 0.01 per minute. The error bars for TEA represented the SD values of three independent experiments as means $\pm \operatorname{SD}(n=3)$.

Based on the optimal alginate lyase production conditions, we set to purify this enzyme (AlyP1400) from Pseudoalteromonas sp. 1400 grown in $9 \mathrm{~L}$ of selection medium with $1.8 \%$ sodium alginate for $24 \mathrm{~h}$ at 
$\mathrm{pH} 8$ and a temperature of $25^{\circ} \mathrm{C}$. Table 2 shows the detailed information of the implemented multi-step purification procedures. The crude AlyP1400 exhibited a specific activity of $17.67 \pm 0.018 \mathrm{U} / \mathrm{mg}$ protein. This value increased to $106.47 \pm 1.4 \mathrm{U} / \mathrm{mg}$ protein after fractionation II with ammonium sulfate $(80 \%)$, while the purified AlyP1400 specific activity that resulted from Bio-Gel column chromatography (Sephadex G-100) was $342.16 \pm 3.84 \mathrm{U} / \mathrm{mg}$ protein.

The achieved enzyme purification fold was 19.36 after bio-gel column chromatography, with a yield of $0.5 \%$. During the first 120 minutes of purification time, no lyase activity was observed with the collected fractions through the bio-gel column chromatography eluate with $0.2 \mathrm{M}$ sodium chloride. The fractions recovered after 180 minutes, and the eluate from 0.3 to $0.4 \mathrm{M}$ sodium chloride showed a specific activity value between $31.8 \pm 2.6$ and $867 \pm 32.75 \mathrm{U} / \mathrm{mg}$ protein. Increasing the purification time beyond 220 minutes significantly reduced the alginate lyase activity (Figure 5). After buffer exchange, we stored the purified AlyP1400 in $20 \mathrm{mM}$ Tris- $\mathrm{HCl}$ ( $\mathrm{pH} 7.5$ ) at $0.7 \mathrm{mg}$ protein/mL final concentration at $-20^{\circ} \mathrm{C}$ until further use.

Table 2. AlyP1400 purification procedures.

\begin{tabular}{|c|c|c|c|c|c|}
\hline $\begin{array}{l}\text { Purification } \\
\text { Proceedings }\end{array}$ & Total Protein (mg) & $\begin{array}{l}\text { Total Enzyme } \\
\text { Activity (U)* }\end{array}$ & $\begin{array}{c}\text { Enzyme Specific } \\
\text { Activity (U/mg Protein) }\end{array}$ & Purification (Fold) & Yield (\%) \\
\hline Crude enzyme & $5126.11 \pm 5.35$ & $90565 \pm 5.0$ & $17.67 \pm 0.018$ & 1.00 & 100 \\
\hline $\begin{array}{l}\text { Fractionation I } \\
60 \%\left(\mathrm{NH}_{4}\right)_{2} \mathrm{SO}_{4}\end{array}$ & $1551.33 \pm 4.16$ & $53375.33 \pm 4.51$ & $34.41 \pm 0.92$ & 1.95 & 59 \\
\hline $\begin{array}{l}\text { Fractionation II } \\
80 \%\left(\mathrm{NH}_{4}\right)_{2} \mathrm{SO}_{4}\end{array}$ & $85.9 \pm 1.13$ & $9123 \pm 3.0$ & $106.47 \pm 1.4$ & 6.03 & 10 \\
\hline $\begin{array}{l}\text { Anion exchange } \\
\text { chromatography } \\
\text { (DEAE Sepharose) }\end{array}$ & $32.166 \pm 1.78$ & $3902.33 \pm 6.81$ & $125.94 \pm 7.32$ & 7.13 & 4.0 \\
\hline $\begin{array}{c}\text { Gel-filtration } \\
\text { chromatography } \\
\text { (Sephadex G-100) }\end{array}$ & $1.17 \pm 0.06$ & $410 \pm 2.0$ & $342.16 \pm 3.84$ & 19.36 & 0.5 \\
\hline
\end{tabular}

Notes: * One-unit (U) enzyme defined as the amount of enzyme required to increase the absorbance at $235 \mathrm{~nm}$ by 0.01 per minute. The mean values of three independent experiments are presented as means $\pm \operatorname{SD}(n=3)$.

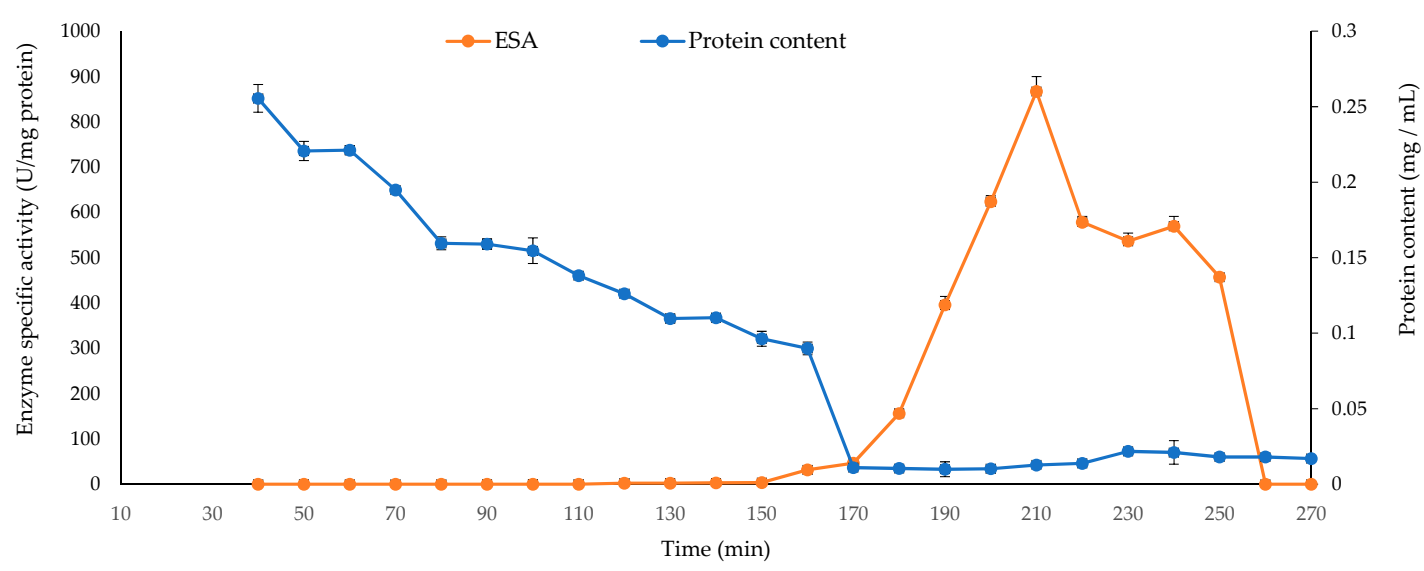

Figure 5. Protein content and specific enzyme activities for AlyP1400 obtained from the Sephadex G100. One-unit enzyme defined as the amount of enzyme required to increase the absorbance at $235 \mathrm{~nm}$ by 0.01 per minute. Error bars represented the SD values of three independent experiments as means \pm SD $(n=3)$.

\subsection{Biochemical Properties of Purified AlyP1400}

AlyP1400 was active for both poly-M and poly-G degradation, indicating that it is a bifunctional alginate lyase (data not shown). SDS-PAGE and zymogram analysis illustrated that the enzyme had a molecular mass of $\sim 23 \mathrm{KDa}$ (Figure 6). To characterize both the thermal and $\mathrm{pH}$ stability of the purified AlyP1400, the enzymatic activity was measured after incubation at different temperatures and then with buffers that had a wide range of $\mathrm{pH}$ values. AlyP1400 activity revealed stability at low 
temperature $\left(10^{\circ} \mathrm{C}\right)$. The maximum activity was recorded at $30^{\circ} \mathrm{C}$, which dramatically decreased when temperature increased to $40{ }^{\circ} \mathrm{C}$. The enzyme was completely inactivated when incubated at $45^{\circ} \mathrm{C}$ (Figure 7a). The highest AlyP1400 activity was recorded when the enzyme was incubated in a buffer with $\mathrm{pH} 6.0$ and about $60 \%$ of its activity was retained at $\mathrm{pH} 7.0$. This activity decreased significantly $(P<0.0001)$ when $\mathrm{pH}$ changed towards either alkaline or acidic conditions. AlyP1400 lost about $43 \%$ of its activity when incubated in buffer with $\mathrm{pH} 5.0$, while more than $90 \%$ of the activity was lost when the AlyP1400 was incubated in $\mathrm{pH} 3.0$ or $\mathrm{pH} 10.0$ buffers (Figure $7 \mathrm{~b}$ ).

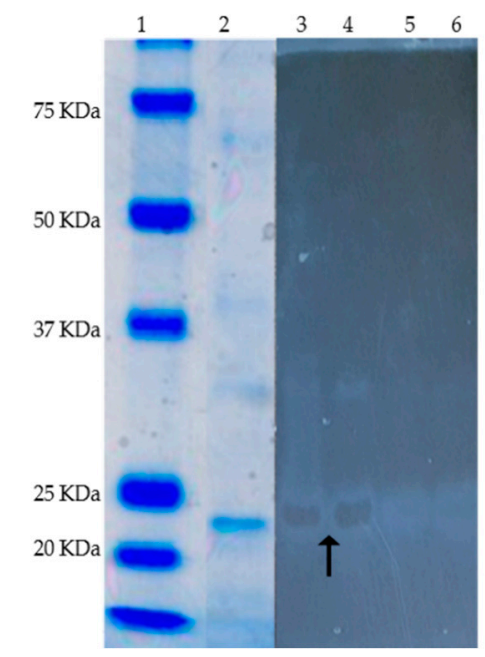

Figure 6. SDS-PAGE (Coomassie blue staining) and zymogram (active staining for alginate lyase) of the purified alginate lyase (AlyP1400) from Pseudoalteromonas sp. 1400. Lanes are as follows, 1 , protein markers; 2,3 and 4 purified alginate lyase (black arrow show the alginate hydrolysis in 3 and 4), 5 and 6 negative control, $0.1 \%$ alginate solution in $20 \mathrm{mM}$ Tis- $\mathrm{HCl}$ buffer.

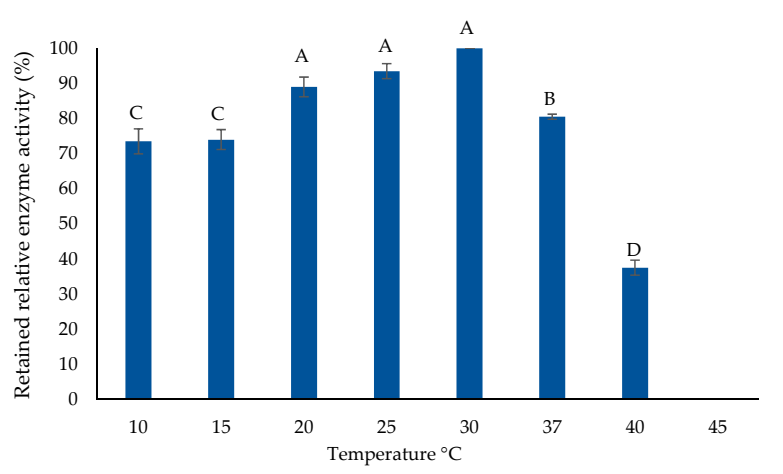

(a)

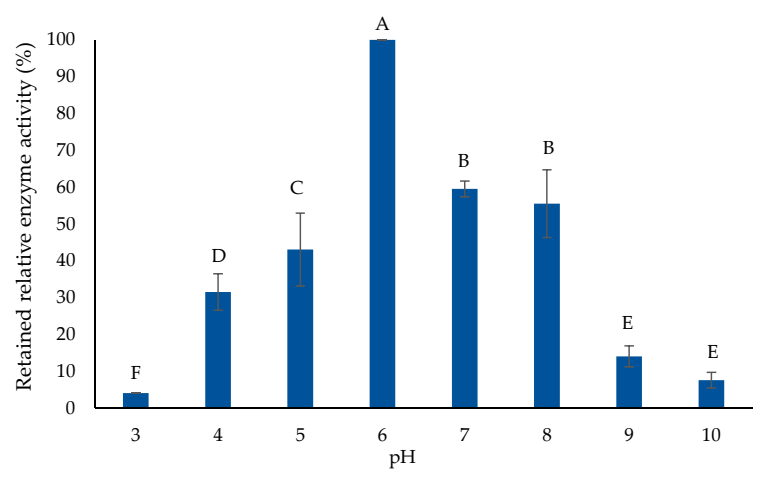

(b)

Figure 7. AlyP1400 biochemical characterization. (a) Thermal enzyme stability and (b) the pH stability of the purified AlyP1400 are illustrated. Error bars represent SD of three independent experiments. Different letters indicate statistically significant differences between groups $(p<0.05)$.

\subsection{Liquid Chromatography Tandem-Mass Spectrometry (LC-MS/MS) Enzyme Analysis}

The AlyP1400 band identified in the SDS-PAGE with alginate lyase activity was excised, subjected to trypsin digestion and analyzed by LC-MS/MS. A protein identification search was performed using Proteome Discover 2.2 software against the broad National Centre for Biotechnology Information (NCBI) Pseudoalteromonadaceae (Taxonomy ID 267888) database in consideration of all possible variants within this bacterial family. The cRAP (Common Repository of Adventitious Proteins) database was also selected to account for common background contaminant proteins typically found in proteomics experiments. A protein named alginase (Entry ACB87607, Pseudoalteromonas sp. SM0524), containing a carbohydrate binding domain and an alginate lyase region, was identified 
as the top scoring protein found in this gel band, excluding a few human keratin protein hits. Seven alginate lyase peptides, including four unique peptides were identified from the LC-MS/MS data (Figure S2). These peptide sequences were further searched using BLAST at the NCBI database. The results showed that the peptide sequencing matched some alginate lyases in the database. The identified N-terminal sequences of AlyP1400 are related to the following: the alginate lyases from Alteromonas sp. 272; the extracellular alginate lyase produced by Pseudoalteromonas sp. IAM14594; a $\beta$-D-mannuoronate lyase from several strains of P. agarivorans, Pseudoalteromonas sp. NW 4327, Pseudoalteromonas sp. P1-25, and P. telluritirucens; and a polysaccharide lyase family 7 protein produced from Gilvimarinus polysaccharolyticus. These finding suggest that AlyP1400 has a higher identity to the alginate lyases in polysaccharide lyase family 18 Aly-sj02 R.

\subsection{Inhibitory Effect of AlyP1400 against P. aeruginosa PA14 Biofilm}

We first used an immunofluorescence experiment to determine alginate production by $P$. aeruginosa PA14 within biofilms after $48 \mathrm{~h}$ that used specific antibodies (Figure 8). PA14 produced alginate on minimal medium, M63, and showed a clear reaction with the P. aeruginosa alginate-specific monoclonal antibody (MAb F429) (Figure 8b). The biofilms grown in M63 in the presence of AlyP1400 $(60 \mu \mathrm{g} / \mathrm{mL})$ was shown to reduce antibody binding to alginate, with little to no alginate staining, indicating the hydrolytic activity of AlyP1400 against the alginate produced by PA14 (Figure 8d). Controls lacking primary antibody (Figure 8a) and non-alginate producer E. coli (cloning strain TOP10) (Figure 8c) were negative for immunofluorescence signals.

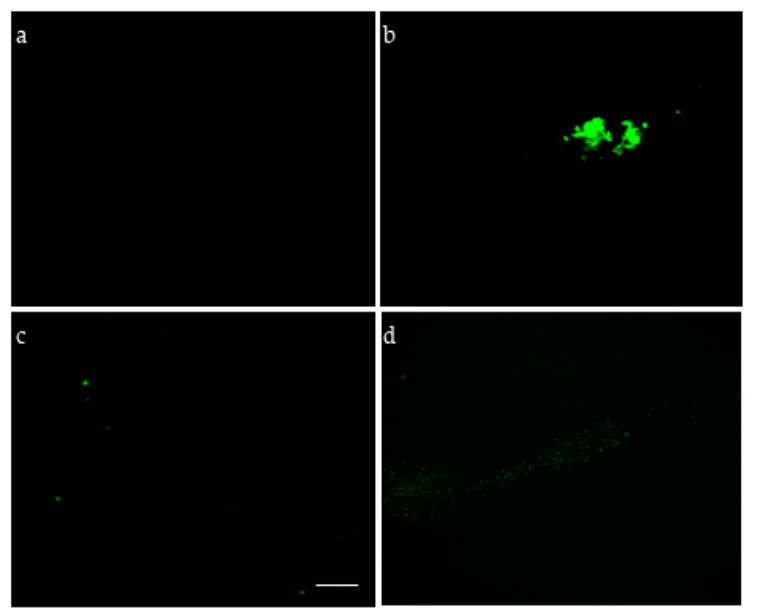

Figure 8. Alginate production by $P$. aeruginosa PA14 grown under biofilm conditions. Fluorescent microscopic images of bacterial cells incubated with MAb F429 and a secondary antibody conjugated with Alexa Fluor 488 are shown. (a) Non-alginate producer E. coli TOP10, (b) P. aeruginosa PA14, (c) P. aeruginosa PA14 control without the primary MAb F429, (d) PA14 with AlyP1400 enzyme. Scale bar, $10 \mu \mathrm{m}$.

To further characterize the activity of the purified AlyP1400 against P. aeruginosa PA14 biofilms, we used a flow-cell biofilm cultivation system to examine the effect of AlyP1400 alone, and in combination with carbenicillin (CB) and ciprofloxacin (Cip) on PA14 biofilms architecture under a continuous flow condition. The 48-h old biofilms pre-formed in a flow-cell chamber were treated for $2 \mathrm{~h}$ and then stained with viability dyes: Syto 61 Red that stains all bacterial cells and emits red fluorescence; while Sytox Green stains cells with permeabilized membranes, damaged or dead cells with compromised membranes, and emits green fluorescence. The non-treated control sample revealed a stable biofilm with a characteristic architecture of mature biofilm and very few to no patches of cells that stained green, indicating that the vast majority of biofilm was living bacteria (Figure S3a). The control biofilm surface had an average thickness of $37.2 \pm 3.74 \mu \mathrm{m}$, biovolume of 
$10.27 \pm 3.77 \mu \mathrm{m}^{3} / \mu \mathrm{m}^{2}$, and surface area of $5.0 \pm 3.5 \mu \mathrm{m}^{2}$ (Table 3). After CB $(100 \mu \mathrm{g} / \mathrm{mL})$ or Cip $(12 \mu \mathrm{g} / \mathrm{mL})$ treatment (without alginate lyase), we found that the antibiotic-treated biofilms were disrupted to non-uniform structures (Figure S3b,c). This was consistent with the significantly reduced average biofilm thickness, which was $27.9 \pm 4.45 \mu \mathrm{m}$ and $27.7 \pm 4.14 \mu \mathrm{m}$ for CB- and Cip-treated samples, respectively (Table 3). The aggregates of membrane compromised cells (green color) were observed in the peripheral area of the antibiotics-treated biofilms, remaining sessile to the glass surface with average biovolumes and surface areas comparable to non-treated control (Table 3). This suggested that the antibiotics only affected the top layer of the biofilms and were not efficient in significantly reducing viable cells protected within the inner layers of the biofilms. Standalone treatment with AlyP1400 (60 $\mu \mathrm{g}$ protein $/ \mathrm{mL}$ ) significantly reduced the biofilm thickness to $25.3 \pm 2.41 \mu \mathrm{m}$, biovolume to $7.71 \pm 3.79 \mu \mathrm{m}^{3} / \mu \mathrm{m}^{2}$, and surface area to $2.6 \pm 1.6 \times 10^{5} \mu \mathrm{m}^{2}$ (Table 3).

Table 3. COMSTAT analyses of remained 48-hour old P. aeruginosa PA14 biofilms treated for 2 hours in flow-cell chambers.

\begin{tabular}{|c|c|c|c|}
\hline Treatments & Average Thickness ( $\mu \mathrm{m})$ & $\begin{array}{l}\text { Biovolume } \\
\left(\mu \mathrm{m}^{3} / \mu \mathrm{m}^{2}\right)\end{array}$ & $\begin{array}{c}\text { Surface Area } \\
\left(10^{5} \mu \mathrm{m}^{2}\right)\end{array}$ \\
\hline Non-treated & $37.2 \pm 3.74$ & $10.27 \pm 3.77$ & $5.0 \pm 3.5$ \\
\hline Carbenicillin (CB) & $27.9 \pm 4.45 *$ & $10.28 \pm 1.26$ & $6.3 \pm 4.0$ \\
\hline Ciprofloxacin (Cip) & $27.7 \pm 4.14$ * & $10.70 \pm 1.0$ & $6.1 \pm 0.1$ \\
\hline AlyP1400 & $25.3 \pm 2.41 *$ & $7.71 \pm 3.79 *$ & $2.6 \pm 1.6^{*}$ \\
\hline AlyP1400 + CB & $16.8 \pm 2.20 * *$ & $5.27 \pm 1.34^{* *}$ & $0.29 \pm 0.2^{* *}$ \\
\hline AlyP1400 + Cip & $13.2 \pm 3.42 * *$ & $3.37 \pm 0.64^{* *}$ & $0.24 \pm 0.1^{* *}$ \\
\hline
\end{tabular}

Notes: The numbers represent the averages of data from three independent experiments, mean values of 30 images are presented as means \pm SD. Carbenicillin $(100 \mu \mathrm{g} / \mathrm{mL})$, ciprofloxacin $(12 \mu \mathrm{g} / \mathrm{mL})$ and AlyP1400 $(60 \mu \mathrm{g}$ protein $/ \mathrm{mL})$. Significant differences are indicated by the follows: no asterisk, $P>0.05,{ }^{*} P<0.05$, and ${ }^{* *} P<0.01$.

Next, the combinational effects for AlyP1400 and conventional antibiotics was tested. The combination of AlyP1400 with either CB or Cip significantly increased the biofilm inhibitory activity of each antibiotic compared to when they were used alone. After treatment with CB or Cip with AlyP1400, the observed biofilms that remained attached to the surface of the flow-cell chamber contained a few small micro-colonies. The treatment of AlyP1400 with CB or Cip significantly reduced the biofilm thickness to $16.8 \pm 2.20 \mu \mathrm{m}$ and $13.2 \pm 3.42 \mu \mathrm{m}$, and surface area to $0.29 \pm 0.20 \times 10^{5} \mu \mathrm{m}^{2}$ and $0.24 \pm 0.10 \times 10^{5} \mu \mathrm{m}^{2}$, respectively (Table 3). The biovolume was reduced significantly to $5.27 \pm 1.34$ and $3.37 \pm 0.64$, respectively (Table 3 ). The treated biofilms were unstable and less structured (Figure S3e,f) compared to the control biofilms (Figure S3a). These remaining cell aggregates appeared to be predominantly dead, as determined by the overlay of the red fluorescent merged with the green fluorescent (Figure S3e,f). The enhanced efficacy of bacterial killing was especially pronounced for $\mathrm{CB}$ and Cip as the membrane compromised cell staining was evident in the micro-colonies of the biofilm. These results were confirmed by the significant reductions in the biofilm thickness, biovolume, and surface area.

\section{Discussion}

Pseudomonas aeruginosa biofilm infection has been a substantial public health problem, mainly due to their antibiotic resistance and defiance of the host defense system. This opportunistic pathogen secrets alginate (polysaccharide-like structure), a unique mucoid architecture, which is the main issue in chronic infection treatments, especially with persistent lung infection of CF patients. Attachment to surfaces is required and stress conditions may induce biofilm formation. Although high doses of antibiotics still represent the most successful medical intervention, it unfortunately doesn't always entirely eradicate the whole bacterial population. Additionally, high levels of antibiotic resistant pathogens usually ensue, hence the development of non-conventional treatment strategies is urgently 
needed [16,36]. Many attempts to eradicate biofilms have been efficiently used, including biofilm prevention, disruption, or eradication $[8,16,19,37,38]$. This work demonstrated that the combined effect of AlyP1400 with conventional antibiotics significantly reduced the notorious P. aeruginosa biofilm.

Recently, alginate lyase activity received much attention, because the alginate enzymatic degradation expands the potential application of this polysaccharide, not only through the industrial applications, but also for curing life threatening infections [39-41]. Extracting alginate lyase enzymes from marine bacteria that possessed alginate depolymerization activity could shift chronic infection treatment strategies. Data shown here confirmed that multiple marine bacterial isolates were able to reduce the alginate solution viscosity by $90 \%$. This is due to the alginate lyase activity, which degrades the alginate to un-saturated uronic acid-containing oligosaccharides via $\beta$-elimination of 1,4-glycosidic [42,43]. Targeting mucoid biofilms with the alginate lyase enzymatic activity can reduce viscosity in clinical strains, and in CF specimens, thereby increasing the phagocytosis activities and enhance the antipseudomonal antibiotics' effects. Consistently, all the supernatants of selected bacterial isolates effectively reduced established P. aeruginosa biofilms. These findings matched with previous reports, which demonstrated that several compounds produced by marine bacteria, particularly Pseudoalteromonas spp., exhibited potential antibiofilm activities against both Gram-positive and Gram-negative bacteria $[40,44-46]$.

Using the purified alginate lyase of Pseudoalteromonas sp. 1400 under static and dynamic conditions against $P$. aeruginosa biofilms on polystyrene and glass surfaces, it was revealed that AlyP1400 impaired biofilm development, compared to the non-treated biofilms and led to subsequent biofilm detachment. This may be due to the hydrolysis of $P$. aeruginosa polysaccharides and disruption of the biofilm architecture that increased dispersal of planktonic cells. In previous studies, the lyase enzyme was also shown to reduce the surface hydrophobicity of newly-formed daughter cells shed from the biofilms [39,47].

The most important finding here is that the co-administration of AlyP1400 with Cip or CB increased the killing efficiency of biofilm cells, which was estimated by measuring the biofilm reduction amount and imaging the remaining attached biofilms to the surface of the flow-cell chamber. In contrast, when Cip or CB was used to treat the established biofilm by themselves, a significant reduction was only observed for the biofilm thickness, as the biovolume and surface area of the antibiotics-treated biofilms were not significantly reduced. It has been shown that biofilm-associated P. aeruginosa cells are more resistant to antibiotic and these cells have increased response and expression of antibiotic resistance genes [48,49]. It was also shown that the addition of exogenous, purified alginate to non-mucoid (alginate-negative) strains enhanced the resistance to killing by macrophages by providing a protective mucus structure for the bacterial cells [50] Meanwhile, when alginate lyase was combined with liposomal aminoglycoside antibiotics to treat $P$. aeruginosa biofilms, a marked improvement in bactericidal activity was noticed. This may be attributed to shutting down the interaction between the liposomal lipids and the alginate, thus preventing their interaction with the bacterial membrane [32]. Although P. aeruginosa produces its own alginate lyase, most of the bacterial lyase enzymes remain in the periplasmic space, and they are only active to assist in expelling the alginate molecules outside the bacterial cells or to assist in releasing cells from the biofilm to colonize a new space [51,52]. There is insufficient evidence regarding the efficiency of $P$. aeruginosa lyase enzyme against its own alginate biofilm. The results of this study provide a promising strategy for biofilm treatment; it can decrease immune evasion and antibiotic resistance of mucoid P. aeruginosa, which support the hypothesis that alginate lyases are promising therapeutic candidates.

\section{Materials and Methods}

Sodium alginate (Macrocystis pyrifera origin, catalog \#A2033) was purchased from Sigma-Aldrich (St. Louis, MO, USA). Bacto Tryptone and Yeast Extract were purchased from Becton and Dickinson (Sparks, MD, USA). The other chemicals were purchased from Fluka Analytical (a Sigma Aldrich company, Oakville, Ontario, Canada). 


\subsection{Bacterial Strains and Growth Conditions}

Pseudomonas aeruginosa strain PA14, a clinical isolate obtained from a burn patient was used in the biofilm cultivation. Medium and growth conditions for PA14 were performed according to O'May and colleagues [53].

\subsection{Isolation of Alginate Lyase Producer Strains}

The collected marine water samples from Queensland Beach, Nova Scotia. (GPS coordinates: $44^{\circ} 38^{\prime} 05.3^{\prime \prime} \mathrm{N} 64^{\circ} 01^{\prime} 40.6^{\prime \prime} \mathrm{W}$ ) at $22.5^{\circ} \mathrm{C}$ and $\mathrm{pH} 8.11$, were used for culturing bacterial isolates with alginate lyase activity, as follows: $10 \mathrm{ml}$ water was shaken in $90 \mathrm{ml}$ enrichment medium $(0.5 \%$ peptone, $0.1 \%$ yeast extract, $0.5 \%$ sodium alginate, $3 \% \mathrm{NaCl}, \mathrm{pH} 6.5$ ) [53] for $48 \mathrm{~h}$ at $28{ }^{\circ} \mathrm{C}$ and $150 \mathrm{rpm}$. Serially diluted cultures were plated on selection medium agar (1\% sodium alginate, $0.5 \%\left(\mathrm{NH}_{4}\right)_{2} \mathrm{SO}_{4}$, $0.2 \% \mathrm{~K}_{2} \mathrm{HPO}_{4} \cdot 3 \mathrm{H}_{2} \mathrm{O}, 0.001 \% \mathrm{FeSO}_{4} \cdot 7 \mathrm{H}_{2} \mathrm{O}, 0.1 \% \mathrm{MgSO}_{4} \cdot 7 \mathrm{H}_{2} \mathrm{O}, 3 \% \mathrm{NaCl}$, and $1.5 \%$ agar, pH 7.0) [54]. Detectable colonies that could grow on selection medium agar were further streak-purified on selection medium agar with $1.8 \%$ sodium alginate.

Purified microorganisms were transferred to plates with selection medium and incubated for $48 \mathrm{~h}$ at $28{ }^{\circ} \mathrm{C}$. Afterward, the entire plate surface was flooded with three $\mathrm{ml}$ of Lugol's solution and the clear zones around bacterial growth that indicates alginate hydrolysis were measured [54]. Morphologically distinct bacterial colonies with large hydrolytic zones were stored at $-80^{\circ} \mathrm{C}$ in a solution of $40 \%$ glycerol with bacterial growth in selection medium broth $(1: 1 \mathrm{v} / \mathrm{v})$ for further alginolytic activity studies.

\subsection{Bacterial Identification}

DNA from isolated microorganisms was prepared for PCR by boiling an isolated colony in $50 \%$ solution of Chelex 100 resin (v/v in sterile water) (Sigma, St. Louis, MO, USA) for $10 \mathrm{~min}$, followed by centrifugation for $10 \mathrm{~min}$ at $10,956 \times \mathrm{g}$. The supernatant was used as a template for PCR method modified from a previously published protocol [55]. GoTaq ${ }^{\circledR}$ Colourless Master Mix (Promega, Madison, WI, USA) was used for the PCRs following the manufacturer's instructions and contained $0.2 \mu \mathrm{M}$ of each primer. Universal 16S primers F1 (5'-AGA GTT TGA TCI TGG CTC AG-3') and R5 (5'-ACG GIT ACC TTG TTA CGA CTT-3') were used for bacterial isolates [55,56]. PCR products were generated using an initial denaturation step for two minutes at $95^{\circ} \mathrm{C}$ followed by 35 cycles of a $60 \mathrm{~s} 95^{\circ} \mathrm{C}$ denaturation, a $30 \mathrm{~s} 58^{\circ} \mathrm{C}$ annealing and a $60 \mathrm{~s} 72{ }^{\circ} \mathrm{C}$ extension. A final extension of $10 \mathrm{~min}$ at $72{ }^{\circ} \mathrm{C}$ was included. PCR products were visualized on a $1 \%$ agarose gel stained with SYBR ${ }^{\circledR}$ Safe DNA Stain (Invitrogen, Carlsbad, CA, USA) under UV light. Upon verifying the presence of the correctly sized single band (1500 bp), the PCR product was cleaned with ExoSAP-IT ${ }^{\circledR}$ (Affymetrix, Santa Clara, CA, USA), following manufacturer's instructions. The cleaned PCR products were sent to Genewiz (South Plainfield, NJ, USA) for sequencing using the same primers that were used for PCR amplification. For a phylogenetic depiction, the sequenced $16 \mathrm{~S}$ rRNA genes for each isolate were compared with the GenBank database using the BLAST program through the NCBI's website [57].

\subsection{Alginolytic Activity and Substrate Specificity of Cell-Free Supernatants}

Bacterial colonies with the highest lyase activity in the clear zone assay above (4.2) were selected for testing their alginolytic activity as follows: three milliliter overnight $(16-18 \mathrm{~h})$ bacterial culture (OD at $600 \mathrm{~nm}$ adjusted to 1.0) was inoculated into a $97 \mathrm{~mL}$ fermentation medium (selection medium with $1.8 \%$ sodium alginate) and incubated at $28^{\circ} \mathrm{C}$ and $150 \mathrm{rpm}$ for $24 \mathrm{~h}$. After the fermentation and centrifugation for $30 \mathrm{~min}$ at $12,096 \times g$ at $4{ }^{\circ} \mathrm{C}$, cell-free supernatants were filtered through $0.22 \mu \mathrm{m}$ non-pyrogenic filters and kept at $-20^{\circ} \mathrm{C}$.

To measure the viscosity of filtered cell-free supernatants, a Brookfield digital viscometer (model LTVD) was use as per the manufacturer's protocol. All triplicate samples were measured at room temperature $\left(25^{\circ} \mathrm{C}\right)$ using Spindle No.1 with varied speed rotation $(60,30$, and $12 \mathrm{rpm})$ according 
to the methods previously mentioned by Pendyala and his colleagues [58] and the non-inoculated fermentation medium was used as a control.

Alginate lyase activities were measured using an absorbance assay at the wavelength of $235 \mathrm{~nm}$. The absorbance of sodium alginate solution was increased due to the formation of a carbon-carbon double bond at the end of the product generated from lyase-mediated cleavage of alginate. Filtered supernatant $(20 \mu \mathrm{L})$ was added to $180 \mu \mathrm{L}$ aliquots of $0.1 \%$ sodium alginate in $20 \mathrm{mM}$ Tris- $\mathrm{HCl}, \mathrm{pH} 7.0$, and was incubated for $30 \mathrm{~min}$ at $37^{\circ} \mathrm{C}$. The reaction was terminated by heating all tubes for $10 \mathrm{~min}$ at $100{ }^{\circ} \mathrm{C}$. Aliquots of preheated supernatants were run in parallel as a control, and the absorbance of the reaction solution was measured at $235 \mathrm{~nm}$ with a spectrophotometer (Eppendorf Bio-photometer Plus). One-unit alginate lyase activity was considered as the amount of enzyme that increased the absorbance by 0.01 per minute. [59]. To test the enzyme specificity, both alginate lyase types, poly-M-specific and poly-G-specific, were distinguishable by white halos and white rings respectively according to the methods reported by Nakagawa and his colleagues [60].

\subsection{Pseudomonas aeruginosa PA14 Biofilm Cultivation in 96-Microtiter Plate}

Pseudomonas aeruginosa PA14 cells were cultured in LB broth overnight at $37^{\circ} \mathrm{C}$ and $200 \mathrm{rpm}$. Cells were harvested by centrifugation at $9,798 \times \mathrm{g}$ for $10 \mathrm{~min}$ at $4{ }^{\circ} \mathrm{C}$. Pelleted cells were washed three times in phosphate buffered saline (PBS, pH 7.5) and resuspended in M63 medium $\left(1.36 \% \mathrm{KH}_{2} \mathrm{PO}_{4}\right.$, $0.2 \%\left(\mathrm{NH}_{4}\right)_{2} \mathrm{SO}_{4}, 0.02 \% \mathrm{MgSO}_{4} \cdot 7 \mathrm{H}_{2} \mathrm{O}$, and $0.2 \%$ glycerol with $\left.\mathrm{pH} 7.0\right)$ supplemented with $0.5 \mathrm{mg} / \mathrm{L}$ $\mathrm{FeSO}_{4} \cdot 7 \mathrm{H}_{2} \mathrm{O}, 0.5 \mu \mathrm{g} / \mathrm{mL}$ vitamin B1, and $1.0 \mu \mathrm{g} / \mathrm{mL}$ L-arginine [61]. Each well of 96 -microtiter plate (polyvinylchloride plastic) was seeded with $190 \mu \mathrm{L}$ M63 medium and $10 \mu \mathrm{L}$ PA14 overnight culture diluted in M63 medium $\left(\mathrm{OD}_{600}=0.5\right)$. After incubation statically at $37^{\circ} \mathrm{C}$ with $95 \%$ relative humidity for $24 \mathrm{~h}$, the medium was removed, the biofilm was fixed with $200 \mu \mathrm{L} 99 \%$ methanol for $15 \mathrm{~min}$ and then stained with $200 \mu \mathrm{L}$ of $1.0 \%$ filtered crystal violet for five minutes on orbital shaker at room temperature $\left(27 \pm 2{ }^{\circ} \mathrm{C}\right)$. Excess stain was removed, and the wells were washed three times with distilled water and dried before biofilm solubilization. Biofilms in each well were dissolved by $200 \mu \mathrm{L}$ absolute ethanol for $30 \mathrm{~s}$, then $125 \mu \mathrm{L}$ of dissolved biofilm was transferred into a new 96-well microtiter plates and analyzed using a plate reader (Bio-Rad Benchmark Plus UV-Visible Plate Reader microplate spectrophotometer) at $570 \mathrm{~nm}[62,63]$. Wells with sterilized medium were used as blank controls.

\subsection{Pseudomonas aeruginosa PA14 Biofilm Inhibition by Cell-Free Supernatants of Pseudoalteromonas and Cellulophaga spp.}

Using the biofilm assay in 96-microtiter plate as described above, each well was seeded with $95 \mu \mathrm{L}$ $\mathrm{M} 63$ medium and $5 \mu \mathrm{L}$ of PA14 overnight culture diluted in M63 medium $\left(\mathrm{OD}_{600}=0.5\right)$. The plate was incubated at $37^{\circ} \mathrm{C}$ with $95 \%$ relative humidity for $48 \mathrm{~h}$. Afterward, each well was topped up with $100 \mu \mathrm{L}$ of filter-sterilized cell-free supernatant of seven selected Pseudoalteromonas and Cellulophaga spp. and was incubated for another $24 \mathrm{~h}$ or $48 \mathrm{~h}$ (two plates in parallel, one for each treatment length). After incubation, the biofilms were then fixed, stained, washed, solubilized and analyzed on at plate reader at $570 \mathrm{~nm}$ as described in the previous section.

\subsection{AlyP1400 Production and Purification}

In order to extract sufficient quantities of lyase, we cultured isolate 1400 under different temperatures, covering the range of $10-45{ }^{\circ} \mathrm{C}$, and $\mathrm{pHs}$, covering the range of $4.0-10$ in order to determine the optimum culture conditions to purify the enzyme. Both the total and specific alginate lyase enzyme activities were measured as described by Zhu and colleagues [59], and the temperature and $\mathrm{pH}$ resulting in the highest enzyme activities were utilized for the following purification procedures. After $24 \mathrm{~h}$ fermentation of selection medium with $1.8 \%$ sodium alginate and pH 8 with Pseudoalteromonas sp. 1400 at $25^{\circ} \mathrm{C}$ and $150 \mathrm{rpm}$, the cell-free supernatant was collected and fractionated with ammonium sulfate between $60 \%$ and $80 \%$ saturation. The protein was precipitated, resuspended in $3.0 \mathrm{~mL}$ of Tris- $\mathrm{HCl}(20 \mathrm{mM}, \mathrm{pH} 7.5)$ and dialyzed against 100 volumes 
of Tris- $\mathrm{HCl}(20 \mathrm{mM}, \mathrm{pH} 7.5)$, at $4{ }^{\circ} \mathrm{C}$ (changed eight times over a $16 \mathrm{~h}$ period) using $12-14 \mathrm{KDa}$ molecular-weight-cut-off dialysis tubing (Baxter, Spectra/POR molecular porous membrane tubing). The salt-free protein sample was freeze-dried using a freeze-dryer (Sharp Freeze-110, AAPPTec) and the powder was dissolved in Tris- $\mathrm{HCl}$ buffer $(20 \mathrm{mM}, \mathrm{pH} 7.5)(4 \% \mathrm{w} / \mathrm{v}$ as a final concentration) to generate an enzyme solution for further analysis and testing. From this solution, both the total and specific alginate lyase enzyme activities were again measured as described by Zhu and colleagues [59], meanwhile protein contents were evaluated according to BCA protein assay kit (Thermo Scientific Pierce BCA Protein Assay Kit) following the manufacturer's instruction. The enzyme solution was applied to a DEAE Sepharose column (Sigma-Aldrich, $16.0 \times 2.0 \mathrm{~cm}$ ) after equilibration with the Tris- $\mathrm{HCl}$ buffer $(20 \mathrm{mM}, \mathrm{pH} 7.5)$, then was eluted by the same buffer with linear gradient of 0.1 to $0.5 \mathrm{M} \mathrm{NaCl}$ at a flow rate of $500 \mu \mathrm{L} / \mathrm{min}$ [64]. Each fraction was collected and measured for enzyme activity and for protein content as described above. Fractions that showed the highest alginolytic activity were pooled, and their purity and molecular mass were detected by sodium dodecyl sulfate polyacrylamide gel electrophoresis (SDS-PAGE) and Zymography $[65,66]$. The pooled fractions with high alginolytic activity from the DEAE Sepharose column were freeze-dried and dissolved in Tris- $\mathrm{HCl}$ buffer $(4.0 \% \mathrm{w} / \mathrm{v}$ as a final concentration) and applied into a Sephadex G100 column (Sigma-Aldrich, $100 \times 1.6 \mathrm{~cm}$ ) that was equilibrated with the same buffer and eluted at a $500 \mu \mathrm{L} / \mathrm{min}$ flow rate. After determining alginate lyase activity, detecting protein content and assessing purity by SDS-PAGE, the purified alginate lyase was stored at $-20^{\circ} \mathrm{C}$.

\subsection{AlyP1400 Characterization}

Alginate lyase thermo-stability was determined by incubating the purified enzyme $60 \mu \mathrm{g}$ protein/mL with sodium alginate $(0.1 \%)$ in Tris- $\mathrm{HCl}$ buffer $(\mathrm{pH} 7.0)$ at different temperature $\left(10-45^{\circ} \mathrm{C}\right)$. The effect of $\mathrm{pH}$ on the enzymatic activity was determined after incubating the purified enzyme at $30^{\circ} \mathrm{C}$ (the optimal temperature determined as above) with sodium alginate $(0.1 \%)$ in buffers with different $\mathrm{pH}$, using phosphate-citrate ( $\mathrm{pH} 3.0-5.0)$, Tris- $\mathrm{HCl}\left(\mathrm{pH}\right.$ 6.0-9.0) or $\mathrm{Na}_{2} \mathrm{HPO}_{4}-\mathrm{NaOH}(\mathrm{pH} 10.0)$ [67]. Both the enzyme thermal stability and $\mathrm{pH}$ stability were detected as the relative enzyme activity by using the total enzyme activity assay, as mentioned above, where the highest measured enzyme activity was considered $100 \%$ and all other measurements were compared relative to that highest amount.

\subsection{Liquid Chromatography Tandem-Mass Spectrometry (LC-MS/MS) Enzyme Analysis}

The purified alginate lyase was resolved on a $10 \%$ SDS separating gel using the SDS-PAGE analysis. The excised gel slices stained with Coomassie blue G-250 were processed for LC-MS/MS as previously described [68], with minor modifications. Briefly, gel slices were rinsed for $2 \mathrm{~h}$ in $\mathrm{dH}_{2} \mathrm{O}$ and then cut into $\sim 1.0 \mathrm{~mm}$ cube and rinsed twice with $200 \mu \mathrm{L}$ of $\mathrm{dH}_{2} \mathrm{O}$. Gel cubes were reduced with $10 \mathrm{mM}$ dithiothreitol (DTT) at $56^{\circ} \mathrm{C}$ for $30 \mathrm{~min}$, alkylated with $55 \mathrm{mM}$ iodoacetamide for $30 \mathrm{~min}$ at room temperature in the dark, and dehydrated with $200 \mu \mathrm{L}$ acetonitrile (ACN). Dried gel cubes were saturated with $20 \mu \mathrm{g} / \mathrm{mL}$ of trypsin protease (Pierce Thermo Scientific) for $2 \mathrm{~h}$, then $20 \mu \mathrm{L}$ of $50 \mathrm{mM}$ ammonium bicarbonate was added and the samples were incubated overnight at $37^{\circ} \mathrm{C}$. Digested peptides were extracted from the gel cubes by treatment with $100 \mu \mathrm{L}$ of $50 \% \mathrm{ACN}$ with $5 \%$ formic acid. The peptide-containing solution was dried to a pellet in a vacuum centrifuge and subsequently resuspended in $20 \mu \mathrm{L}$ of a $3 \% \mathrm{ACN}$, $0.5 \%$ formic acid solution.

The samples were transferred to a $300 \mu \mathrm{L}$ HPLC vial and subject to analysis by LC-MS/MS on a VelosPRO orbitrap mass spectrometer (Thermo Fisher Scientific) equipped with an UltiMate 3000 Nano-LC system (Thermo Fisher Scientific). Chromatographic separation of the digests was performed on PicoFRIT C18 self-packed $75 \mathrm{~mm} \times 60 \mathrm{~cm}$ capillary column (New Objective, Woburn, MA) at a flow rate of $300 \mu \mathrm{L} / \mathrm{min}$. MS and MS/MS data were acquired using a data-dependent acquisition method in which a full scan was obtained at a resolution of 30,000, followed by ten consecutive MS/MS spectra in both higher-energy collisional dissociation (HCD) and collision-induced dissociation (CID) mode (normalized collision energy $36 \%$ ). Internal calibration was performed using the ion signal of 
polysiloxane at m/z 445.120025 as a lock mass. Raw MS data were analyzed using Proteome Discoverer 2.1 (Thermo Fisher Scientific). Peak lists were searched in Uniprot's Pseudoalteromonadaceae database as well as the cRAP database of common contaminants (Global Proteome Machine Organization). Cysteine carbamidomethylation was set as a fixed modification, while methionine (Met) oxidation, N-terminal Met loss, and phosphorylation on serine, threonine, and tyrosine were included as variable modifications. A mass accuracy tolerance of 5 ppm was used for precursor ions, while 0.02 Da for HCD fragmentation or 0.6 Da for CID fragmentation was used for product ions. Percolator [69] was used to determine confident peptide identifications using a $0.1 \%$ false discovery rate (FDR).

\subsection{Inhibitory Effect of AlyP1400 against P. aeruginosa PA14 Biofilm}

Alginate production by PA14 was evaluated after $48 \mathrm{~h}$ incubation at $37^{\circ} \mathrm{C}$ in 96 -microtiter plate filled with M63 medium. Alginolytic hydrolytic activity of AlyP1400 was assayed by incubating $60 \mu \mathrm{g} / \mathrm{mL}$ AlyP1400 with PA14 under the same conditions. A monoclonal antibody MAb F429 (kindly provided as a gift by Dr. Gerald Pier, Harvard Medical School, Boston, Massachusetts) was used to stain the PA14 biofilms recovered from the microtiter plate (with or without AlyP1400) as described previously [70]. Briefly, smears of $100 \mu \mathrm{L}$ of recovered biofilms were air-dried and fixed with methanol 99\% on glass slides, washed and stained for alginate production by immunofluorescence using MAb F429 at $1 \mathrm{mg} / \mathrm{mL}$ or a control solution lacking the primary antibody. A non-alginate producer (E. coli TOP10, Invitrogen; Cat\# LSC404010) was used as negative control. After incubation $1 \mathrm{~h}$ at $37^{\circ} \mathrm{C}$, the smears were washed three times with phosphate-buffered saline and covered with $100 \mu \mathrm{L}$ of 1:500 dilution of donkey anti-rabbit immunoglobulin G Alexa Fluor 488 (Molecular Probes/Invitrogen, Carlsbad, CA) and incubated at $37^{\circ} \mathrm{C}$ for $1 \mathrm{~h}$ in the dark. After washing, the smears were visualized for alginate production using fluorescence microscope (Model Zeiss LSM 510, Carl Zeiss, Germany) with argon $(488 \mathrm{~nm})$ used with an oil-immersion 63x objective.

After confirming PA14 alginate production and AlyP1400 alginate lyase activity on the alginate, the inhibitory effects of AlyP1400 with and without antibiotics was assessed against established biofilms formed in dynamic conditions. To establish the biofilms, overnight cultures of PA14 in LB were centrifuged and washed three times in PBS. Cells were resuspended in M63 medium and adjusted to $\mathrm{OD}_{600}=0.5$. Three channel flow-cell $(1 \times 40 \times 44 \mathrm{~mm}$; BioCentrum, DTU, Denmark $)$ was assembled and sterilized flowing the manufacturer's instructions. Each channel was injected with $250 \mu \mathrm{L}$ of PA14 cell suspension as prepared above. The whole flow cell system was incubated statically for $2 \mathrm{~h}$ at $37^{\circ} \mathrm{C}$. The biofilms were developed on the glass substratum of the flow-cell with $48 \mathrm{~h}$ of incubation at $37^{\circ} \mathrm{C}$ under dynamic conditions $(0.2 \mathrm{~mm} / \mathrm{s}$ linear flow rate) [71]. To determine the effect of AlyP1400 activity combined with antibiotics against the attached biofilm, the flow-cell was incubated at a static condition for $30 \mathrm{~min}$ before each channel was injected with $250 \mu \mathrm{L}$ of one the following: M63 medium (control), AlyP1400 (60 $\mu \mathrm{g}$ protein/mL in Tris-HCl buffer), CB (100 $\mu \mathrm{g} / \mathrm{mL})$, Cip $(12 \mu \mathrm{g} / \mathrm{mL})$, AlyP1400 with CB (1:1 v/v), and AlyP1400 with Cip (1:1 v/v). Each flow cell was kept under static conditions for another $2 \mathrm{~h}$ and then each channel was stained for 30 min with $250 \mu \mathrm{L}, 10 \mu \mathrm{M}$ Syto 61 Red (Thermo Fisher Scientific, Invitrogen) that stains all living cells and fluoresces red (excitation at $628 \mathrm{~nm}$, emission at $645 \mathrm{~nm}$ ), followed by $250 \mu \mathrm{L}, 10 \mu \mathrm{M}$ Sytox Green (Thermo Fisher Scientific, Invitrogen) for $30 \mathrm{~min}$, which stains membrane compromised cells and fluoresces green (excitation at $504 \mathrm{~nm}$, emission at $523 \mathrm{~nm}$ ) to determine the cell death. Confocal laser scanning microscope (Model Zeiss LSM 510, Carl Zeiss, Germany) with argon (488 nm) and a helium neon laser $(543 \mathrm{~nm}$ ) was used to image the biofilms with an oil-immersion 63x objective. The $488 \mathrm{~nm}$ laser and a $500 \mathrm{~nm}-550 \mathrm{~nm}$ band pass emission filter and the $543 \mathrm{~nm}$ laser with a long pass $560 \mathrm{~nm}$ emission filer were used to excite and detect the stained biofilms. Images $(n=10)$ were scanned sequentially at $488 \mathrm{~nm}$ and $543 \mathrm{~nm}$ for biofilms after the treatments and were processed using Zen 2009 image software. PA14 clusters were identified as any bacterial assemblages with a thickness more than $10.0 \mu \mathrm{m}$. Quantitative analysis of fluorescence microscopic images (captured through Z-stack) obtained from flow cell-grown biofilms was performed with COMSTAT image analysis software [72]. 


\subsection{Statistical Analyses}

Statistical analyses were performed using GraphPad Prism software (version 7.0; GraphPad Software, Inc, La Jolla, CA, USA). ANOVA one-way and two-way tests were used to determine any statistically significant difference between different experimental conditions and biofilm structural parameters obtained from COMSTAT analysis of CLSM images. Differences were considered statistically significant when $P<0.05$.

\section{Conclusions}

A polysaccharide lyase AlyP1400, with high activity against alginate substrate, has been purified from marine bacterium Pseudoalteromonas sp. 1400. This enzyme had a molecular mass at $23 \mathrm{KDa}$ and revealed a broad $\mathrm{pH}$ range for high enzyme activity and thermo-stability with a bifunctional lyase activity for both poly-M and poly-G degradation. AlyP1400 efficiently diminished P. aeruginosa PA14 biofilms when combined with conventional antibiotic, as the biofilm thickness, biovolume and surface area were reduced after treatment with carbenicillin or ciprofloxacin combined with the lyase enzyme. This result provides the knowledge basis to develop a combination treatment strategy, which targets alginates or polysaccharide matrices within bacterial biofilms in order to enhance the efficacy of known, clinically used antibiotics.

Supplementary Materials: The following are available online at http://www.mdpi.com/1660-3397/17/5/307/s1, Figure S1: Biofilm biomass formed after $48 \mathrm{~h}$ in 96 -well microplates, treated with different cell-free supernatants for $48 \mathrm{~h}$ at $37^{\circ} \mathrm{C}$ under static conditions, Figure S2: Peptide-spectra matches obtained from the in-gel tryptic digestion of AlyP1400 analyzed by LC-MS/MS, Figure S3: Selected representative images of P. aeruginosa PA14 biofilms grown under dynamic conditions on glass surface at $37^{\circ} \mathrm{C}$, for $48 \mathrm{~h}$ under a flow of M63 medium exposed to different treatments.

Author Contributions: Conceptualization, S.M.D., J.R., and Z.C.; formal analysis, S.M.D., R.R., and A.C.; funding acquisition, S.M.D. and Z.C.; writing-original draft preparation, S.M.D.; writing-review and editing, S.M.D., R.R., A.C., J.R. and Z.C.

Funding: This research was funded by the Cystic Fibrosis Canada Marsha Morton Early Career Investigator award, a Natural Science and Engineering Research Council of Canada Discovery Grant (grant number: RGPIN/04912-2016), and a Nova Scotia Lung Association Legacy Grant to Z.C. This project was also supported by a Nova Scotia Health Research Foundation catalyst grant to Z.C. and S.D.

Acknowledgments: We would like to thank Stephen Whitefield at the Cellular \& Molecular Digital Imaging (CMDI) core facility for the assistance in confocal microscopy experiments. The MS identification was carried out in the Proteomics core facility. Both the CMDI and Proteomics core facilities are maintained as part of the Centralized Operation of Research Equipment and Support program of Dalhousie's Faculty of Medicine. We appreciate the anti-Pseudomonas aeruginosa alginate antibody MAb F429 as a generous gift from Dr. Gerald Pier from the Brigham and Women's Hospital, Harvard Medical School.

Conflicts of Interest: The authors declare no conflict of interest.

\section{References}

1. Costerton, J.W. Introduction to biofilm. Int. J. Antimicrob. Agents 1999, 11, 217-221. [CrossRef]

2. Hall-Stoodley, L.; Costerton, J.W.; Stoodley, P. Bacterial biofilms: From the natural environment to infectious diseases. Nat. Rev. Microbiol. 2004, 2, 95-108. [CrossRef]

3. Hall-Stoodley, L.; Stoodley, P. Biofilm formation and dispersal and the transmission of human pathogens. Trends Microbiol. 2005, 13, 7-10. [CrossRef]

4. Bjarnsholt, T.; Klaus, K.M.; Peter, Ø.J; Kit, G.M.; Richard, P.; Karen, K.; Niels, H.; Michael, G. Why chronic wounds will not heal: A novel hypothesis. Wound Repair Regen. 2008, 16, 2-10. [CrossRef]

5. Bjarnsholt, T.; Jensen, P.; Fiandaca, M.J.; Pedersen, J.; Hansen, C.R.; Andersen, C.B.; Pressler, T.; Givskov, M.; Høiby, N. Pseudomonas aeruginosa biofilms in the respiratory tract of cystic fibrosis patients. Pediatr. Pulmonol. 2009, 44, 547-558. [CrossRef] [PubMed]

6. Ramsey, M.M.; Whiteley, M. Pseudomonas aeruginosa attachment and biofilm development in dynamic environments. Mol. Microbiol. 2004, 53, 1075-1087. [CrossRef] 
7. Karatan, E.; Watnick, P. Signals, regulatory networks, and materials that build and break bacterial biofilms. Microbiol. Mol. Biol. Rev. 2009, 73, 310-347. [CrossRef] [PubMed]

8. Bernardes, E.T.; Charron-Mazenod, L.; Reading, D.J.; Reckseidler-Zenteno, S.L.; Lewenza, S. Exopolysaccharide-repressing small molecules with antibiofilm and antivirulence activity against Pseudomonas aeruginosa. Antimicrob. Agents Chemother. 2017, 61, e01997-16. [CrossRef]

9. Davies, D. Understanding biofilm resistance to antibacterial agents. Nat. Rev. Drug Discov. 2003, 2, 114-122. [CrossRef]

10. Flemming, H.C.; Wingender, J. The biofilm matrix. Nat. Rev. Microbiol. 2010, 8, 623-633. [CrossRef]

11. Bjarnsholt, T.; Jensen, P.Ø.; Jakobsen, T.H.; Phipps, R.; Nielsen, A.K.; Morten, T.R.; Tim, T.N.; Michael, G.; Niels, H.; Oana, C. Quorum sensing and virulence of Pseudomonas aeruginosa during lung infection of cystic fibrosis patients. PLoS ONE 2010, 5, e10115. [CrossRef]

12. Chua, S.L.; Louise, D.H.; Mingjun, Y.; Morten, R.; Thomas, E.N.; Michael, G.; Tim, T.N.; Liang, Y. In vitro and in vivo generation and characterization of Pseudomonas aeruginosa biofilm-dispersed cells via c-di-GMP manipulation. Nat. Protoc. 2015, 10, 1165-1170. [CrossRef] [PubMed]

13. Gnanadhas, D.P.; Monalisha, E.; Akshay, D.; Dipshikha, C. Chronic lung infection by Pseudomonas aeruginosa biofilm is cured by L-Methionine in combination with antibiotic therapy. Sci. Rep. 2015, 5, 16043. [CrossRef]

14. Francolini, I.; Donelli, G. Prevention of biofilm-based medical-device-related infections. FEMS Immunol. Med. Microbiol. 2010, 59, 227-238. [CrossRef]

15. Drenkard, E. Antimicrobial resistance of Pseudomonas aeruginosa biofilms. Microbes Infect. 2003, 5, 1213-1219. [CrossRef]

16. Reffuveille, F.; de la Fuente-Nùñez, C.; Mansour, S.; Hancock, R.E. A broad-spectrum antibiofilm peptide enhances antibiotic action against bacterial biofilms. Antimicrob. Agents Chemother. 2014, 58, 5363-5371. [CrossRef] [PubMed]

17. Bjarnsholt, T.; Jensen, P.; Burmølle, M.; Morten, H.; Janus, A.J.H.; Hans, P.H.; Henrik, C.; Kit, G.M.; Claus, M.; Søren, M.; et al. Pseudomonas aeruginosa tolerance to tobramycin, hydrogen peroxide and polymorphonuclear leukocytes is quorum-sensing dependent. Microbiology 2005, 151, 373-383. [CrossRef]

18. Williams, B.J.; Dehnbostel, J.; Blackwell, T.S. Pseudomonas aeruginosa: Host defense in lung diseases. Respirology 2010, 15, 1037-1056. [CrossRef]

19. Hassett, D.J.; Cuppoletti, J.; Trapnell, B.; Lymar, S.V.; Rowe, J.J.; Yoon, S.S.; Hilliard, G.M.; Parvatiyar, K.; Kamani, M.C.; et al. Anaerobic metabolism and quorum sensing by Pseudomonas aeruginosa biofilms in chronically infected cystic fibrosis airways: Rethinking antibiotic treatment strategies and drug targets. Adv. Drug Deliv. Rev. 2002, 54, 1425-1443. [CrossRef]

20. Wagner, V.E.; Iglewski, B.H. Pseudomonas aeruginosa biofilms in CF Infection. Clin. Rev. Allergy Immunol. 2008, 35, 124-134. [CrossRef] [PubMed]

21. Rowntree, R.K.; Ann, H. The phenotypic consequences of CFTR mutations. Ann. Hum. Genet. 2003, 67, 471-485. [CrossRef]

22. Boucher, R.C. New concepts of the pathogenesis of cystic fibrosis lung disease. Eur. Respir. J. 2004, 23, 146-158. [CrossRef] [PubMed]

23. Kirov, S.M.; Webb, J.S.; Kjelleberg, S. Clinical significance of seeding dispersal in biofilms. Microbiology 2005, 151, 3452-3453. [CrossRef]

24. Kirov, S.M.; Webb, J.S.; O’May, C.Y.; Reid, D.W.; Woo, J.; Rice, S.A.; Kjelleberg, S. Biofilm differentiation and dispersal in mucoid Pseudomonas aeruginosa isolates from patients with cystic fibrosis. Microbiology 2007, 153, 3264-3274. [CrossRef]

25. Anderson, G.G.; Moreau-Marquis, S.; Stanton, B.A.; O’Toole, G.A. In vitro analysis of tobramycin-treated Pseudomonas aeruginosa biofilms on cystic fibrosis-derived airway epithelial cells. Infect. Immun. 2008, 1423-1433. [CrossRef]

26. Woo, J.K.K.; Webb, J.S.; Kirov, S.M.; Kjelleberg, S.; Rice, S.A. Biofilm dispersal cells of a cystic fibrosis Pseudomonas aeruginosa isolate exhibit variability in functional traits likely to contribute to persistent infection. FEMS Immunol. Med. Microbiol. 2012, 66, 251-264. [CrossRef]

27. Murphy, T.F.; Brauer, A.L.; Eschberger, K.; Lobbins, P.; Grove, L.; Cai, X.; Sethi, S. Pseudomonas aeruginosa in chronic obstructive pulmonary disease. Am. J. Respir. Crit. Care Med. 2008, 177, 853-860. [CrossRef] 
28. Hengzhuang, W.; Wu, H.; Ciofu, O.; Song, Z.; Høiby, N. Pharmacokinetics/pharmacodynamics of colistin and imipenem on mucoid and nonmucoid Pseudomonas aeruginosa Biofilms. Antimicrob. Agents Chemother. 2011, 5, 4469-4474. [CrossRef]

29. Trizna, E.; Bogachev, M.I.; Kayumov, A. Degrading of the Pseudomonas aeruginosa biofilm by extracellular levanase SacC from Bacillus subtilis. BioNanoScience 2018, 9, 48-52. [CrossRef]

30. Nijland, R.; Hall, M.J.; Burgess, J.G. Dispersal of biofilms by secreted, matrix degrading, bacterial DNase. PLoS ONE 2010, 5, e15668. [CrossRef]

31. Baker, P.; Hill, P.J.; Snarr, B.D.; Alnabelseya, N.; Pestrak, M.; Lee, M.J.; Jennings, L.K.; Tam, J.; Melnyk, R.A.; Parsek, M.R.; et al. Exopolysaccharide biosynthetic glycoside hydrolases can be utilized to disrupt and prevent Pseudomonas aeruginosa biofilms. Sci. Adv. 2016, 2, e1501632. [CrossRef]

32. Alipour, M.; Suntres, Z.E.; Omri, A. Importance of DNase and alginate lyase for enhancing free and liposome encapsulated aminoglycoside activity against Pseudomonas aeruginosa. J. Antimicrob. Chemother. 2009, 64, 317-325. [CrossRef] [PubMed]

33. Zhu, Y.; Liyun, W.; Yanhong, C.; Hui, N.; Anfeng, X.; Huinong, C. Characterization of an extracellular biofunctional alginate lyase from marine Microbulbifer sp. ALW1 and antioxidant activity of enzymatic hydrolysates. Microbiol. Res. 2016, 182, 49-58. [CrossRef] [PubMed]

34. Dufourcq, R.; Chalkiadakis, E.; Fauchon, M.; Deslandes, E.; Kerjean, V.; Chanteau, S.; Petit, E.; Guezennec, J.; Dupont-Rouzeyrol, M. Isolation and partial characterization of bacteria (Pseudoalteromonas sp.) with potential antibacterial activity from a marine costal environment from New Caledonia. Lett. Appl. Microbiol. 2014, 58, 102-108. [CrossRef] [PubMed]

35. Dheilly, A.; Soum-Soutéra, E.; Klein, G.L.; Bazire, A.; Compère, C.; Haras, D.; Dufour, A. Antibiofilm activity of the marine bacterium Pseudoalteromonas sp. strain 3J6. Appl. Environ. Microbiol. 2010, 76, 3452-3461. [CrossRef] [PubMed]

36. Høiby, N.; Ciofu, O.; Johansen, H.K.; Song, Z.J.; Moser, C.; Jensen, P.; Molin, S.; Givskov, M.; Tolker-Nielsen, T.; Bjarnsholt, T. The clinical impact of bacterial biofilms. Int. J. Oral Sci. 2011, 3, 55-65. [CrossRef]

37. Bjarnsholt, T.; Ciofu, O.; Molin, S.; Givskov, M.; Høiby, N. Applying insights from biofilm biology to drug development-Can a new approach be developed? Nat. Rev. Drug Discov. 2013, 12, 791-808. [CrossRef] [PubMed]

38. Lamppa, J.W.; Karl, E.G. Alginate lyase exhibits catalysis-independent biofilm dispersion and antibiotic synergy. Antimicrob. Agents Chemother. 2013, 57, 137-145. [CrossRef]

39. Nithya, C.; Shunmugiah, K.P. The In vitro antibiofilm activity of selected marine bacterial culture supernatants against Vibrio spp. Arch. Microbiol. 2010, 192, 843-854. [CrossRef] [PubMed]

40. Hu, X.; Xiaolu, J.; Hueymin, H.; Shiliang, L.; Huashi, G. Antitumor activities of alginate-derived oligosaccharides and their sulphated substitution derivatives. Eur. J. Phycol. 2004, 39, 67-71. [CrossRef]

41. Hu, X.; Xiaolu, J.; Jun, G.; Hueymin, H.; Yan, L.; Huashi, G. Antibacterial activity of lyase-depolymerized products of alginate. J. Appl. Phycol. 2005, 17, 57-60. [CrossRef]

42. Wong, T.Y.; Preston, L.A.; Schiller, N.L. Alginate lyase: Review of major sources and enzyme characteristics, structure-function analysis, biological roles, and application. Annu. Rev. Microbiol. 2000, 54, 289-340. [CrossRef]

43. Ertesvåg, H. Alginate-modifying enzymes: Biological roles and biotechnological uses. Front. Microbiol. 2015, 6, 523. [CrossRef]

44. Rendueles, O.; Kaplan, J.B.; Ghigo, J.M. Antibiofilm polysaccharides. Environ. Microbiol. 2013, 15, $334-346$. [CrossRef] [PubMed]

45. Papa, R.; Ermenegilda, P.; Filomena, S.; Gaetano, B.; Maria, L.T.; Marco, A.; Laura, S. Anti-biofilm activity of the Antarctic marine bacterium Pseudoalteromonas haloplanktis TAC125. Res. Microbiol. 2013, 164, 450-456. [CrossRef] [PubMed]

46. Richards, G.P.; Watson, M.A.; Needleman, D.S.; Uknalis, J.; Boyd, E.F.; Fay, J.P. Mechanisms for Pseudoalteromonas piscicida induced killing of vibrios and other bacterial pathogens. Appl. Environ. Microbiol. 2017, 83, e00175-17. [CrossRef]

47. Klein, G.L.; Soum-Soutéra, E.; Guedec, Z.; Bazirea, A.; Compere, C.; Dufoura, A. The anti-biofilm activity secreted by a marine Pseudoalteromonas strain. Biofouling 2011, 27, 931-940. [CrossRef] [PubMed] 
48. Walters, M.C.; Roe, F.; Bugnicourt, A.; Franklin, M.J.; Stewart, P.S. Contributions of antibiotic penetration, oxygen limitation, and low metabolic activity to tolerance of Pseudomonas aeruginosa biofilms to ciprofloxacin and tobramycin. Antimicrob. Agents Chemother. 2003, 47, 317-323. [CrossRef]

49. Hall, C.W.; Hinz, A.J.; Gagnon, L.B.; Zhang, L.; Nadeau, J.P.; Copeland, S.; Saha, B.; Mah, T.F. Pseudomonas aeruginosa biofilm antibiotic resistance gene $n d v B$ expression requires the RpoS stationary-phase sigma factor. Appl. Environ. Microbiol. 2018, 19, e02762-17. [CrossRef]

50. Leid, J.G.; Willson, C.J.; Shirtliff, M.E.; Hassett, D.J.; Parsek, M.R.; Jeffers, A.K. The exopolysaccharide alginate protects Pseudomonas aeruginosa biofilm bacteria from IFN $\gamma$-mediated macrophage killing. J. Immunol. 2005, 175, 7512-7518. [CrossRef]

51. Lamppa, J.W.; Ackerman, M.E.; Lai, J.I.; Scanlon, T.C.; Griswold, K.E. Genetically engineered alginate lyase-PEG conjugates exhibit enhanced catalytic function and reduced immunoreactivity. PLoS ONE 2011, 6, e17042. [CrossRef] [PubMed]

52. Robles-Price, A.; Wong, T.Y.; Sletta, H.; Valla, S.; Schiller, N.L. AlgX is a periplasmic protein required for alginate biosynthesis in Pseudomonas aeruginosa. J. Bacteriol. 2004, 186, 7369-7377. [CrossRef] [PubMed]

53. O'May, C.Y.; Reid, D.W.; Kirov, S.M. Anaerobic culture conditions favor biofilm-like phenotypes in Pseudomonas aeruginosa isolates from patients with cystic fibrosis. FEMS Immunol. Med. Microbiol. 2006, 48, 373-380. [CrossRef] [PubMed]

54. Li, L.; Xiaolu, J.; Huashi, G.; Peng, W. Preparation, purification and characterization of alginate oligosaccharides degraded by alginate lyase from Pseudomonas sp. HZJ 216. Carbohydr. Res. 2011, 346, 794-800. [CrossRef]

55. Weisburg, W.G.; Barns, S.M.; Pelletier, D.A.; Lane, D.J. 16 S ribosomal DNA amplification for phylogenetic study. J. Bacteriol. 1991, 173, 697-703. [CrossRef] [PubMed]

56. Babalola, O.O.; Bronwyn, M.K.; Marilize, L.R.; Andrew, E.C.; Cary, C.S.; Stephanie, G.B.; Don, A.C. Phylogenetic analysis of actinobacterial populations associated with Antarctic Dry Valley mineral soils. Environ. Microbiol. 2009, 11, 566-576. [CrossRef]

57. Boratyn, G.M.; Christiam, C.; Peter, S.C.; George, C.; Amelia, F.; Ning, M.; Thomas, L.M.; Wayne, T.M.; Scott, D.M.; Yuri, M.; Yan, R.; Eric, W.S.; Tao, T.; Jian, Y.; Irena, Z. BLAST: A more efficient report with usability improvements. Nucleic Acids Res. 2013, 41, W29-W33. [CrossRef]

58. Pendyala, V.; Baburao, C.; Chandrasekhar, K. Studies on some physicochemical properties of Leucaena leucocephala bark gum. J. Adv. Pharm. Technol. Res. 2010, 1, 253-259.

59. Zhu, Z.; Xiangqian, L.; Hao, S.; Jia, Z.; Zhongbiao, T.; Mengdi, Y.; Peng, Y.; Xiaoyan, L. Characterization of a novel alginate lyase from marine bacterium Vibrio furnissii H1. Mar. Drugs 2018, 16, 30. [CrossRef]

60. Nakagawa, A.; Ozaki, T.; Chubachi, K.; Hosoyama, T.; Okubo, T.; Iyobe, S.; Suzuki, T. An effective method for isolating alginate lyase-producing Bacillus sp. ATB-1015 strain and purification and characterization of the lyase. J. Appl. Microbiol. 1998, 84, 328-335. [CrossRef]

61. O’Toole, G.A. Microtiter dish biofilm formation assay. J. Vis. Exp. 2011, 47, e2437. [CrossRef] [PubMed]

62. Stepanovic, S.; Dragana, V.; Veronika, H.; Giovanni, D.B.; Slobodanka, D.; Ivana, C.; Filip, R. Quantification of biofilm in microtiter plates: Overview of testing conditions and practical recommendations for assessment of biofilm production by staphylococci. APMIS 2007, 115, 891-899. [CrossRef]

63. O'Toole, G.A.; Kolter, R. Initiation of biofilm formation in Pseudomonas fluorescens WCS365 proceeds via multiple, convergent signaling pathways: A genetic analysis. Mol. Microbiol. 1998, 28, 449-461. [CrossRef] [PubMed]

64. Li, J.W.; Sheng, D.; Jie, S.; Chun-Bo, L.; Xiu-Lan, C.; Bin-Bin, X.; Yu-Zhong, Z. Purification and characterization of a bifunctional alginate lyase from Pseudoalteromonas sp. SM0524. Mar. Drugs 2011, 9, 109-123. [CrossRef]

65. Laemmli, U.K. Cleavage of structural proteins during assembly of the head of bacteriophage T4. Nature 1970, 227, 680-685. [CrossRef]

66. Ana, P.; Antonio, P. Detection of alginate lyase activity staining after sodium dodecyl sulfate-polyacrylamide gel electrophoresis and subsequent renaturation. Analyt. Biochem. 1994, 217, 124-127. [CrossRef]

67. Chen, X.L.; Zhang, Y.Z.; Gao, P.J.; Luan, X.W. Two different proteases produced by a deep-sea psychrotrophic strain Pseudoaltermonas sp. SM9913. Mar. Biol. 2003, 143, 989-993. [CrossRef]

68. Lukas, K.; Jesse, D.C.; Jason, W.; William, S.N.; Michael, J.M. Semi-supervised learning for peptide identification from shotgun proteomics datasets. Nat. Methods 2007, 4, 923-925. [CrossRef] 
69. Shevchenko, A.; Tomas, H.; Havliš, J.; Olsen, J.V.; Mann, M. In-gel digestion for mass spectrometric characterization of proteins and proteomes. Nat. Protoc. 2006, 1, 2856-2860. [CrossRef]

70. Zaidi, T.; Pier, G.B. Prophylactic and therapeutic efficacy of a fully human immunoglobulin G1 monoclonal antibody to Pseudomonas aeruginosa alginate in murine keratitis infection. Infect. Immun. 2008, 76, 4720-4725. [CrossRef]

71. Heffernan, B.; Cormac, D.M.; Eoin, C. Comparison of planktonic and biofilm cultures of Pseudomonas fluorescens DSM 8341 cells grown on fluoroacetate. J. Appl. Environ. Microbiol. 2009, 75, 2899-2907. [CrossRef] [PubMed]

72. Heydorn, A.; Nielsen, A.T.; Hentzer, M.; Sternberg, C.; Givskov, M.; Ersboll, B.K.; Molin, S. Quantification of biofilm structures by the novel computer program COMSTAT. Microbiology 2000, 146, 2395-2407. [CrossRef]

(C) 2019 by the authors. Licensee MDPI, Basel, Switzerland. This article is an open access article distributed under the terms and conditions of the Creative Commons Attribution (CC BY) license (http://creativecommons.org/licenses/by/4.0/). 